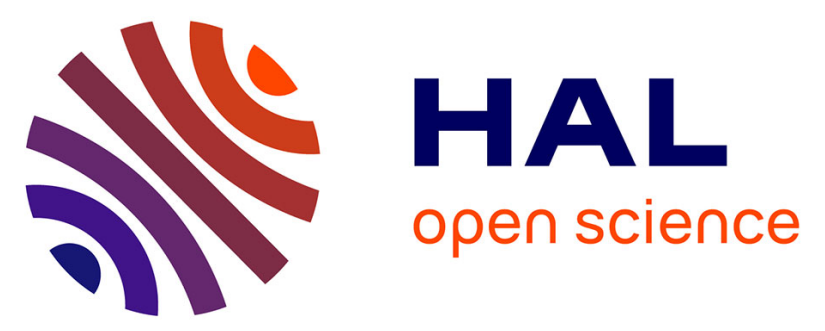

\title{
Natural spatial variability of algal endosymbiont density in the coral Acropora globiceps: a small-scale approach along environmental gradients around Moorea (French Polynesia)
}

Ophélie Ladrière, Lucie Penin, Elodie van Lierde, Jeremie Vidal-Dupiol, Mohsen Kayal, Stephane Roberty, Mathieu Poulicek, Mehdi Adjeroud

\section{To cite this version:}

Ophélie Ladrière, Lucie Penin, Elodie van Lierde, Jeremie Vidal-Dupiol, Mohsen Kayal, et al.. Natural spatial variability of algal endosymbiont density in the coral Acropora globiceps: a small-scale approach along environmental gradients around Moorea (French Polynesia). Journal of the Marine Biological Association of the UK, 2013, pp.1-10. 10.1017/S0025315413001252 . hal-00905942

\section{HAL Id: hal-00905942 \\ https://hal.science/hal-00905942}

Submitted on 30 Jan 2014

HAL is a multi-disciplinary open access archive for the deposit and dissemination of scientific research documents, whether they are published or not. The documents may come from teaching and research institutions in France or abroad, or from public or private research centers.
L'archive ouverte pluridisciplinaire HAL, est destinée au dépôt et à la diffusion de documents scientifiques de niveau recherche, publiés ou non, émanant des établissements d'enseignement et de recherche français ou étrangers, des laboratoires publics ou privés. 


\title{
Natural spatial variability of algal endosymbiont density in the coral Acropora globiceps: a small-scale approach along environmental gradients around Moorea (French Polynesia)
}

\author{
OPHÉLIE LADRIÈrE ${ }^{1}$, LUCIE PENIN ${ }^{2,3}$, ELODIE VAN LIERDE ${ }^{1,4}$, JEREMIE VIDAL-DUPIOL ${ }^{4,5}$, \\ MOHSEN KAYAL ${ }^{3,6}$, STÉPHANE ROBERTY ${ }^{1}$, MATHIEU POULICEK ${ }^{1}$ AND MEHDI ADJEROUD ${ }^{6}$ \\ ${ }^{1}$ Unit of Marine Ecology, Laboratory of Animal Ecology and Ecotoxicology, University of Liège, allée du 6 août, 15, Bat. B6C, B-40oo \\ Liège (Sart Tilman), Belgium, ${ }^{2}$ Laboratoire d'Écologie Marine, FRE CNRS UR 3560 ECOMAR, and Laboratoire d'Excellence \\ 'CORAIL', Université de La Réunion, BP 7151, 97715 Saint-Denis Cedex 09, Réunion Island, France, ${ }^{3}$ USR 3278 CNRS EPHE, \\ Centre de Recherches Insulaires et Observatoire de l'Environnement and Laboratoire d'Excellence 'CORAIL', Université de \\ Perpignan 66860 Perpignan Cedex, France, ${ }^{4}$ CNRS, Ecologie et Evolution des Interactions, UMR 5244 CNRS-UPVD, 58 Avenue \\ Paul Alduy, 66860, Perpignan, France, ${ }^{5}$ Université de Perpignan Via Domitia, Ecologie et Evolution des Interactions, UMR 5244 \\ CNRS-UPVD, 58 Auenue Paul Alduy, 66860, Perpignan, France, ${ }^{6}$ Institut de Recherche pour le Développement, U227 CoRéUs 2 \\ 'Biocomplexité des récifs coralliens de l'Indo-Pacifique' and Laboratoire d'Excellence 'CORAIL', BP A5, 98848 Nouméa, \\ New Caledonia
}

\begin{abstract}
This study provides a baseline describing natural small scale variability of Symbiodinium density in the sentinel coral Acropora globiceps during the summer, under non-bleaching conditions. Spatial scales investigated range from the colony scale (1-10 cm, i.e. among branches of the same colony) to the reef scale (1-10 km, i.e. among stations distributed over several locations and depths), at Moorea Island, French Polynesia. The coral-Symbiodinium symbiosis is a key process in scleractinian coral physiology, and Symbiodinium density provides an easy-to-measure and inexpensive biomarker of this symbiosis health. Spatial variability of three major environmental factors: light intensity, sedimentation and water motion was also assessed to evaluate their potential link with Symbiodinium density. Density of Symbiodinium did not significantly differ within colonies or among colonies within a station. However, a marked depth gradient was observed, showing increasing density with increasing depth and decreasing light intensity. These observations provide an interesting reference for forthcoming comparisons with disturbed conditions, such as bleaching events.
\end{abstract}

Keywords: Symbiodinium density, multi-scale variability, scleractinian corals, symbiosis, environmental gradients

Submitted 28 November 2012; accepted 14 August 2013; first published online 18 September 2013

\section{INTRDDUCTION}

Reef-building corals live in a symbiotic association with unicellular dinoflagellate algae, referred to as zooxanthellae (genus Symbiodinium). Translocated algal photosynthates satisfy most host energetic requirements and are essential for coral survival in oligotrophic tropical shallow waters (Muscatine \& Porter, 1977). Algal symbionts supply the coral host with sugars, glycerol and amino acids, while algae benefit from host metabolic products, such as $\mathrm{CO}_{2}$, phosphates and nitrogenous compounds (Hallock, 2001).

Corresponding author:

L. Penin

Email: lucie.penin@univ-reunion.fr
Symbiodinium density in coral colonies varies at several spatial and temporal scales, both under normal conditions (i.e. in the absence of perturbation) and after particular disturbances. Algal endosymbiont density can vary among coral species (Drew, 1972), as well as among colonies of the same species, at both local and regional scales (Fitt et al., 2001). Light (D'Croz et al., 2001; Bhagooli \& Yakovleva, 2004), sedimentation and eutrophication (Brodie et al., 2007; Sawall et al., 2011), water motion (Finelli et al., 2006), water temperature (Steen \& Muscatine, 1987; Sunagawa et al., 2008) and salinity (Hoegh-Guldberg \& Smith, 1989; Sunagawa et al., 2008) are known to influence the density of Symbiodinium. Despite these advances, the amount and causes of variability in coral algal endosymbionts density at a small spatial scale, i.e. from the colony scale $(1-10 \mathrm{~cm})$ to the reef scale $(1-10 \mathrm{~km})$, remain poorly documented in natural populations. The symbiotic relationship between 
Symbiodinium and its coral host is vulnerable and highly sensitive to environmental or anthropogenic disturbances, and may be disrupted (Bhagooli \& Yakovleva, 2004; Weis, 2008). The disruption of this symbiosis is commonly referred to as coral bleaching, which is broadly defined as the drastic loss of endosymbiotic dinoflagellates or their associated pigments from the coral host cells (Douglas, 2003). Mass-bleaching events, which occur over large spatial scale, are typically associated with higher than average seawater temperature periods (Goreau \& Hayes, 1994; Baker et al., 2008), often in conjunction with increased light (Lesser et al., 1990). These events can cause mass mortality within coral populations and subsequent cascading effects on coral-associated fauna (McClanahan et al., 2009; Leal et al., 2012), and may induce a long-term shift in the composition of reef assemblages (Adjeroud et al., 2009). Surviving coral colonies often show decreased growth and fecundity, reduction in competitive abilities and increased susceptibility to diseases (McClanahan et al., 2009). In recent decades, mass bleaching events have raised increasing concern, especially in the present situation of climate change (Baker et al., 2008). In this context, studies have been set up to estimate coral reef health and document the consequences and extent of catastrophic disturbances such as mass bleaching events. Most of these programmes only document the abundance of coral colonies, and do not take into account physiological processes underlying coral health, such as the coral-Symbiodinium relationship (Fitt et al., 2001). However, estimating coral-Symbiodinium symbiosis health through measures of parameters such as Symbiodinium density has been demonstrated to be relevant in studies investigating bleaching events (see, for example, Fagoonee et al., 1999; Stimson et al., 2002; Shenkar et al., 2006; Li et al., 2008). In this context, documenting Symbiodinium density variation under natural, non-bleaching conditions is critical to provide a baseline allowing comparisons when a bleaching event occurs. This is especially true in the present context of climate change, in reef systems under the influence of recurrent mass bleaching events, such as islands of the Central Pacific (Salvat, 1992; Adjeroud et al., 2005, 2009; Penin et al., 2007, 2013).

In this context, the present study aims at documenting intra-colony and small scale natural spatial variation in Symbiodinium density in a sentinel coral species under nonbleaching conditions during the summer season (warm period). Symbiodinium density was chosen because it is an inexpensive and easy-to-measure variable that is a good proxy for the health of the coral-Symbiodinium relationship (Moothien-Pillay et al., 2005). The method used can be implemented in many locations with very basic laboratory equipment (Bürker type haemocytometer and dissecting microscope).

The present study documents intra-colony variation (colony scale: $1-10 \mathrm{~cm}$ ) as well as small spatial scale variation in the field thanks to a hierarchical sampling design encompassing the station scale $(1-10 \mathrm{~m})$, the location scale $(50-$ $100 \mathrm{~m})$, and the reef scale $(4-7 \mathrm{~km})$. Additional measurements of light intensity, sedimentation rate, and water motion allowed the spatial patterns of variation of these key environmental factors to be compared with Symbiodinium density, thus providing a better understanding of the implications of these factors for the coral-Symbiodinium relationship in the field.

\section{MATERIALS AND METHODS}

\section{Sampling strategy}

The present study focused on the coral Acropora globiceps (Dana, 1846), a major reef-building species in Moorea. Acropora globiceps is a ubiquitous species in the Society Archipelago, abundant both in the lagoon and on the whole depth range of the outer slope, and is easy to identify in the field. It is widespread in the Indo-Pacific, from the central Indian Ocean (Andaman Sea) to south central Pacific (Pitcairn) via the Great Barrier Reef, Micronesia and Polynesia (Wallace, 1999). It is also highly sensitive to changes of environmental conditions, and particularly to temperature variations, like most species of this genus (Marshall \& Baird, 2000; Penin et al., 2007, 2013; Kayal et al., 2011). As a consequence, A. globiceps can be considered as a sentinel species and an adequate candidate for surveys documenting coral health in the Society Archipelago.

Moorea Island $\left(17^{\circ} 30^{\prime} \mathrm{S}, 149^{\circ} 50^{\prime} \mathrm{W}\right.$, Society Archipelago, French Polynesia) exhibits a narrow coral reef belt surrounding the island, which compresses the spatial organization along highly marked environmental gradients (Adjeroud, 1997); therefore, it is a unique system to study spatial variability of Symbiodinium density and the role environmental factors may play in causing these patterns.

First, colony scale variability of Symbiodinium density was studied at three different depths $(6,12$ and $18 \mathrm{~m})$ at one site (Vaipahu). At each of these three depths, eight colonies were randomly chosen. For each colony, the extremity of four branches ( $2 \mathrm{~cm}$ long apex), two internal, and two external, were collected for comparison of Symbiodinium density (Oliver, 1984).

A hierarchical sampling design (Figure 1), which includes various depths and locations was used to determine small spatial scale variation of Symbiodinium density: (1) at the station scale $(1-10 \mathrm{~m})$, among colonies within a sampling station; (2) at the location scale $(50-100 \mathrm{~m})$, among stations implemented at different depths $(6,12$ and $18 \mathrm{~m})$ within a location; and (3) at the reef scale $(4-7 \mathrm{~km})$, among three locations within the outer reef slope of Moorea Island (Figure 1: Haapiti on the west coast, Tiahura and Vaipahu on the north coast; see Penin et al. (2007) for habitat description). Since no significant differences were observed at the colony scale, small spatial scale variability was assessed through sampling three branches of each of eight colonies randomly chosen within a $100 \mathrm{~m}^{2}$ area at the nine sampling stations.

Because Symbiodinium density is known to vary seasonally (Fagoonee et al., 1999; Moothien-Pillay et al., 2005), coral samples were collected in March 2007, which is the warmest month of the year in Moorea (CRIOBE temperature data), in order to provide a baseline corresponding to warm period, i.e. when mass bleaching events are most likely to happen (Adjeroud et al., 2009). Indeed, about one month after the sampling, the first signs of bleaching were observed around Moorea (mid-April; Penin et al., 2013).

\section{Sample analysis}

Coral samples were initially preserved at $-20^{\circ} \mathrm{C}$. Tissues of the frozen fragments were then separated from the coral skeleton with a high-pressure water jet (Water-Pick ${ }^{\mathrm{TM}}$; 


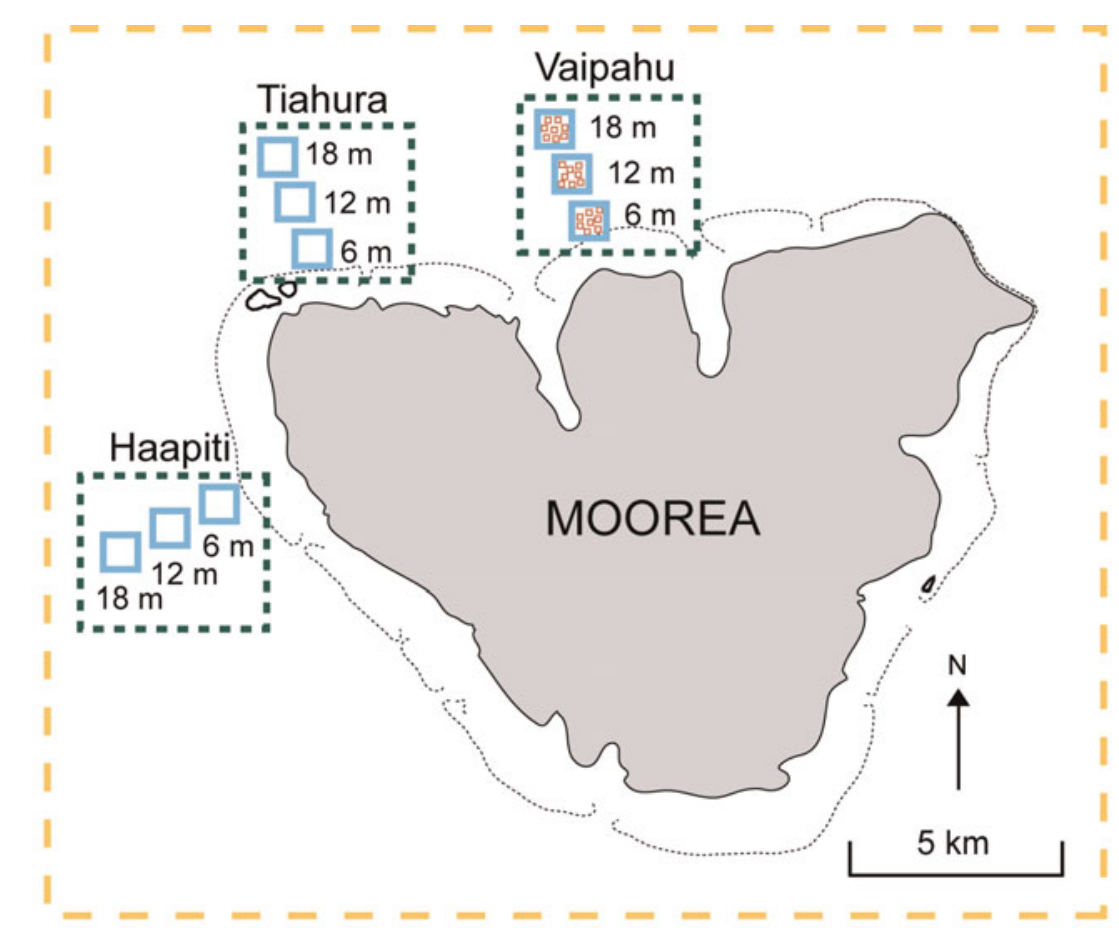

Colony scale $(1-10 \mathrm{~cm})$ : among branches within a colony

Station scale (1-10 m): among colonies within a station
- - - Location scale $(50-100 \mathrm{~m})$ : among stations within a location

r - Reef scale (4-7 km): among locations within the islands reefs

Fig. 1. Map of Moorea indicating the position of the nine sampling stations encompassing three locations (Haapiti, Tiahura and Vaipahu) and three depths (6, 12 and $18 \mathrm{~m}$ ) on the outer reef slope. Variation of Symbiodinium density has been characterized at the colony scale as well as at three different hierarchical small spatial scales represented by different line patterns. Distances among stations within a location are not to scale.

Fitt et al., 2000) using $0.22 \mu \mathrm{m}$-filtered seawater $(50 \mathrm{ml}$ per sample) and allowed to settle. The slurry was then ground in a glass tissue homogenizer and fixed with $4 \%$ formalin for further counts and observations (Lasker, 2003). Density was determined from counts of three replicate aliquots, using a haemocytometer (Bürker type), under an optical microscope. The Symbiodinium cell counts were normalized to total coral surface using a paraffin method adapted from Chancerelle (2000), based on the weight difference between the clean and dry skeleton and the same skeleton coated with paraffin (i.e. sealing fragments of coral skeletons with a varnish and single dipping in paraffin wax at $65^{\circ} \mathrm{C}$ ).

Other methods exist to document coral-Symbiodinium symbiosis performances (see for example Frade et al., 2008a, b). However, they imply using expensive equipment and laboratory facilities (such as aquarium systems, pulse-amplitude modulation fluorometers, etc.), that are not always available, especially in remote locations like

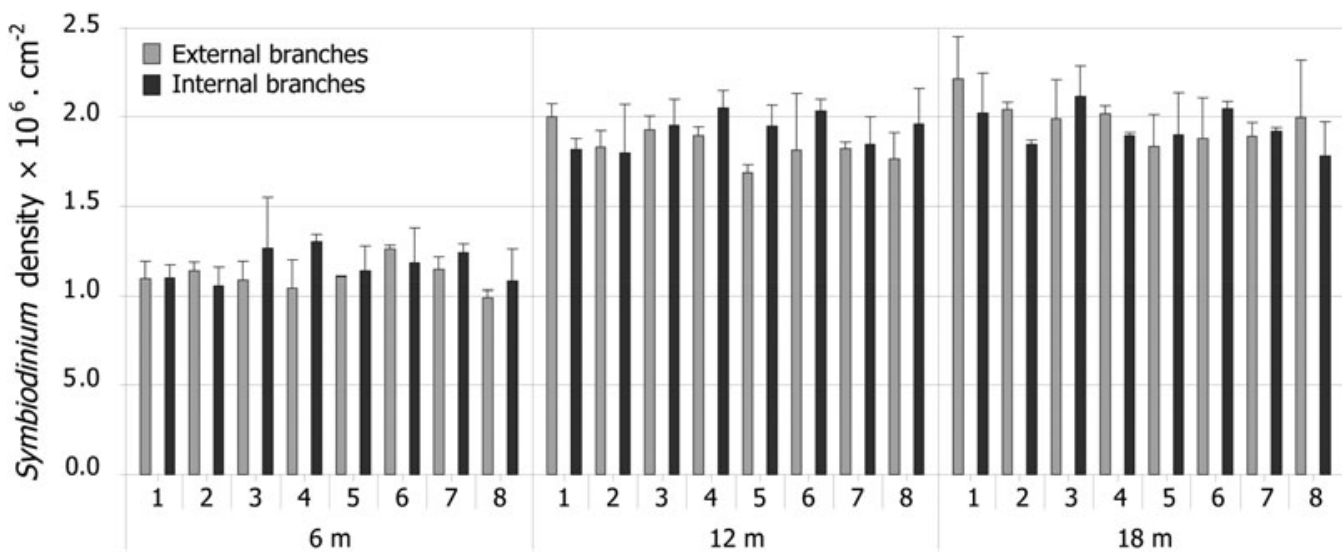

Fig. 2. Colony-scale variation of Symbiodinium densities: mean Symbiodinium density (zoox.cm ${ }^{-2}$ ) in external vs internal branches for each of the eight colonies (1-8) sampled at each of the three depths $(6,12$ and $18 \mathrm{~m})$ at Vaipahu site. Error bars represent standard deviations. 
Table 1. Non-parametric statistical analysis of spatial variation of Symbiodinium density at the colony, station, location and reef scales.

Colony scale

Mann - Whitney (MW) tests, internal vs external branches.

$\alpha_{1}$ (without Bonferroni correction $)=0.0500 ; \alpha_{2}$ (with Bonferroni correction $)=0.0125$

\begin{tabular}{|c|c|c|c|c|}
\hline Depth & $\mathrm{U}$ & $P$ & sig. with $\alpha_{1}$ & sig. with $\alpha_{2}$ \\
\hline All depths & 1200.00 & 0.4059 & NS & NS \\
\hline $6 \mathrm{~m}$ & 111.00 & 0.1657 & NS & NS \\
\hline $12 \mathrm{~m}$ & 108.00 & 0.0875 & NS & NS \\
\hline $18 \mathrm{~m}$ & 111.00 & 0.5217 & NS & NS \\
\hline
\end{tabular}

Station scale

Kruskall-Wallis (KW) tests among colonies within stations.

$\alpha_{1}$ (without Bonferroni correction) $=0.0500 ; \alpha_{2}$ (with Bonferroni correction) $=0.0056$

\begin{tabular}{|c|c|c|c|c|}
\hline Station & $\mathbf{H}$ & $P$ & sig. with $\alpha_{1}$ & sig. with $\alpha_{2}$ \\
\hline Haapiti 6 m & 6.813 & 0.4486 & NS & NS \\
\hline Haapiti $12 \mathrm{~m}$ & 3.000 & 0.8850 & NS & NS \\
\hline Haapiti $18 \mathrm{~m}$ & 15.293 & 0.0324 & * & NS \\
\hline Tiahura $6 \mathrm{~m}$ & 7.640 & 0.3654 & NS & NS \\
\hline Tiahura $12 \mathrm{~m}$ & 1.840 & 0.9682 & NS & NS \\
\hline Tiahura $18 \mathrm{~m}$ & 10.080 & 0.1841 & NS & NS \\
\hline Vaipahu $6 \mathrm{~m}$ & 10.240 & 0.1754 & NS & NS \\
\hline Vaipahu $12 \mathrm{~m}$ & 10.893 & 0.1433 & NS & NS \\
\hline Vaipahu $18 \mathrm{~m}$ & 3.173 & 0.8685 & NS & NS \\
\hline
\end{tabular}

Location scale

KW tests among stations within sites, and MW pairwise post-hoc tests (6 vs $12 \mathrm{~m}, 6 \mathrm{vs} 18 \mathrm{~m}$, and $12 \mathrm{vs} 18 \mathrm{~m}$ ).

$\alpha_{1}$ (without Bonferroni correction) $=0.0500 ; \alpha_{2}$ (with Bonferroni correction) $=0.0042$

KW tests

\begin{tabular}{llll}
\hline Location & H & $\boldsymbol{P}$ & sig. with $\boldsymbol{\alpha}_{\mathbf{1}}$ \\
\hline Haapiti & 47.39 & $<0.0001$ & $*$ \\
Tiahura & 61.941 & $<0.0001$ & $*$ \\
Vaipahu & 59.909 & $<0.0001$ & $*$ \\
\hline
\end{tabular}

MW tests

\begin{tabular}{|c|c|c|c|c|}
\hline Station & $\mathbf{U}$ & $P$ & sig. with $\alpha_{1}$ & sig. with $\alpha_{2}$ \\
\hline Haapiti $6 \mathrm{~m}$ vs Haapiti $12 \mathrm{~m}$ & 0.00 & $<0.0001$ & * & $*$ \\
\hline Haapiti $6 \mathrm{~m}$ vs Haapiti $18 \mathrm{~m}$ & 0.00 & $<0.0001$ & * & $*$ \\
\hline Haapiti $12 \mathrm{~m}$ vs Haapiti $18 \mathrm{~m}$ & 272.00 & $<0.0001$ & * & $*$ \\
\hline Tiahura $6 \mathrm{~m}$ vs Tiahura $12 \mathrm{~m}$ & 0.00 & $<0.0001$ & * & $*$ \\
\hline Tiahura $6 \mathrm{~m}$ vs Tiahura $18 \mathrm{~m}$ & 0.00 & $<0.0001$ & * & $*$ \\
\hline Tiahura $12 \mathrm{~m}$ vs Tiahura $18 \mathrm{~m}$ & 11.00 & $<0.0001$ & * & $*$ \\
\hline Vaipahu $6 \mathrm{~m}$ vs Vaipahu $12 \mathrm{~m}$ & 0.00 & $<0.0001$ & * & $*$ \\
\hline Vaipahu $6 \mathrm{~m}$ vs Vaipahu $18 \mathrm{~m}$ & 0.00 & $<0.0001$ & * & $*$ \\
\hline Vaipahu $12 \mathrm{~m}$ vs Vaipahu $18 \mathrm{~m}$ & 31.00 & $<0.0001$ & * & $*$ \\
\hline
\end{tabular}

\section{Reef scale}

KW tests among locations and MW pairwise post-hoc tests (Haapiti vs Tiahura, Haapiti vs Vaipahu, and Tiahura vs Vaipahu).

$\alpha_{1}$ (without Bonferroni correction) $=0.0500 ; \alpha_{2}$ (with Bonferroni correction) $=0.0125$

KW test

\begin{tabular}{|c|c|c|c|c|}
\hline & $\mathbf{H}$ & $P$ & sig. with $\alpha_{1}$ & sig. with $\alpha_{2}$ \\
\hline Moorea & 0.371 & 0.8305 & NS & NS \\
\hline \multicolumn{5}{|l|}{ MW tests } \\
\hline Station & $\mathbf{U}$ & $P$ & sig. with $\alpha_{1}$ & sig. with $\alpha_{2}$ \\
\hline Haapiti vs Tiahura & 2506.00 & 0.7311 & NS & NS \\
\hline Haapiti vs Vaipahu & 2448.00 & 0.5651 & NS & NS \\
\hline Tiahura vs Vaipahu & 2509.00 & 0.7402 & NS & NS \\
\hline
\end{tabular}


the French Polynesian islands. Symbiodinium counting method used in the present study presents the advantage of being easy to implement with basic laboratory equipment.

\section{Environmental factors}

To identify major factors potentially associated with spatial variations of Symbiodinium density, light intensity (relative photosynthetic photon flux, rPPF, in $\mu$ mol. $\mathrm{m}^{-2} . \mathrm{s}^{-1}$ ), sedimentation (total sedimentation rate, SR, in $\mathrm{mg} \cdot \mathrm{cm}^{-2} \cdot \mathrm{d}^{-1}$ ), and water motion (diffusion factor, DF) were measured at each station. Variability in light intensity was assessed through a relative photosynthetic photon flux (rPPF), which is calculated as the ratio between underwater and surface photosynthetic photon flux (PPF, $\mu$ mol. $\mathrm{m}^{-2} \cdot \mathrm{s}^{-1}$ ), within the range of the photosynthetically active radiations (400$700 \mathrm{~nm}$ ). Measures were made using a MQ-200 quantum meter (Apogee Instruments Inc., Logan UT, USA) at zenith and on cloud-free days. For each replicate, underwater and surface PPF were measured five times within $60 \mathrm{~s}$ at each of five random replicate plots. Three replicates were performed at each station, on three different days. Variability in water motion was characterized through comparison of diffusion factor (DF), calculated as the ratio between weight loss of clod cards deployed in the field for $24 \mathrm{~h}$ and weight loss of identical cards kept in a motionless seawater tank (Thompson \& Glenn, 1994). At each station, five replicate racks, each encompassing four clod cards, were used on each of five randomly chosen days. Variability in sedimentation was quantified through a comparison of dry sediment weight deposited per $\mathrm{cm}^{2}$ and per day. At each station, five sediment collectors were deployed for ten days in three replicate periods, following Stewart et al. (2006). Temperature was not measured, because it does not significantly vary within the studied depth range at these sites during the warm season (Penin et al., 2007).

\section{Statistical analysis}

Due to lack of normality and homoscedasticity of the distributions of Symbiodinium densities, even after appropriate transformations, parametric statistics like ANOVA could not be used. As a consequence, non-parametric statistical analyses were used. Intra-colony comparisons (between internal and external branches) were performed using MannWhitney rank tests (MW). For comparisons among stations, locations and depths, Kruskal-Wallis rank tests (KW) were conducted, completed by MW rank tests for post-hoc pairwise comparisons. Spatial variability of light intensity, water motion, and sedimentation rate were explored through the use of KW rank tests and complementary MW rank tests for pairwise comparisons. Non-parametric Spearman correlations were used to detect significant relationships between variability of Symbiodinium density and variability of light intensity, sedimentation, and water motion among the nine sampling stations. Results are presented with two values of $\alpha$, the first one being the classical 0.05 , and the second one being the $\alpha$ obtained after standard Bonferroni corrections, which is a method aiming at adjusting the $\alpha$ risk to the number of tests run, thus limiting the risk of Type I errors (i.e. rejecting Ho when Ho is true). Results were virtually identical with the two methods, but we choose to present both due to controversy raised by the use of Bonferroni corrections (Cabin \& Mitchell, 2000; Moran, 2003).

\section{RESULTS}

Symbiodinium density ranged from 0.77 to $2.32 \times 10^{6} \mathrm{~cm}^{-2}$. No difference was observed between internal and external branches at the Vaipahu site, whatever the depth being considered (Figure 2; Table 1). Similarly, Symbiodinium density did not significantly vary at the station scale (i.e. among colonies within a sampling station, Table 1). In contrast, significantly higher densities were observed at deep stations than at shallow stations at all three locations (Figure 3; Table 1). Marked gradients were also observed among the nine sampling stations for the measured environmental variables. The rPPF decreased with increasing depth, but no significant variation was observed among locations (Figure 4; Table 2). Total dry sediment weight did not vary among depths, but was significantly lower at Haapiti than at Vaipahu or Tiahura (Figure 4; Table 2). Diffusion factor decreased with

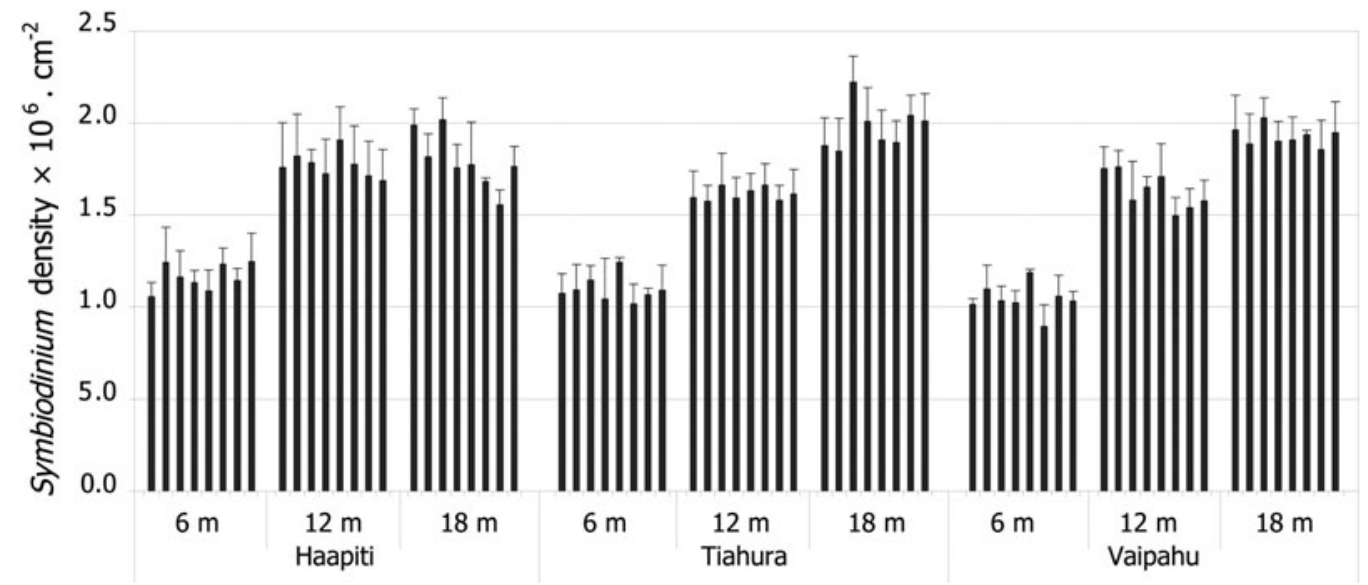

Fig. 3. Multi-scale variation of Symbiodinium densities: mean Symbiodinium density (zoox.cm ${ }^{-2}$ ) for each of the eight colonies sampled at each of the nine study stations around Moorea. Error bars represent standard deviations. 

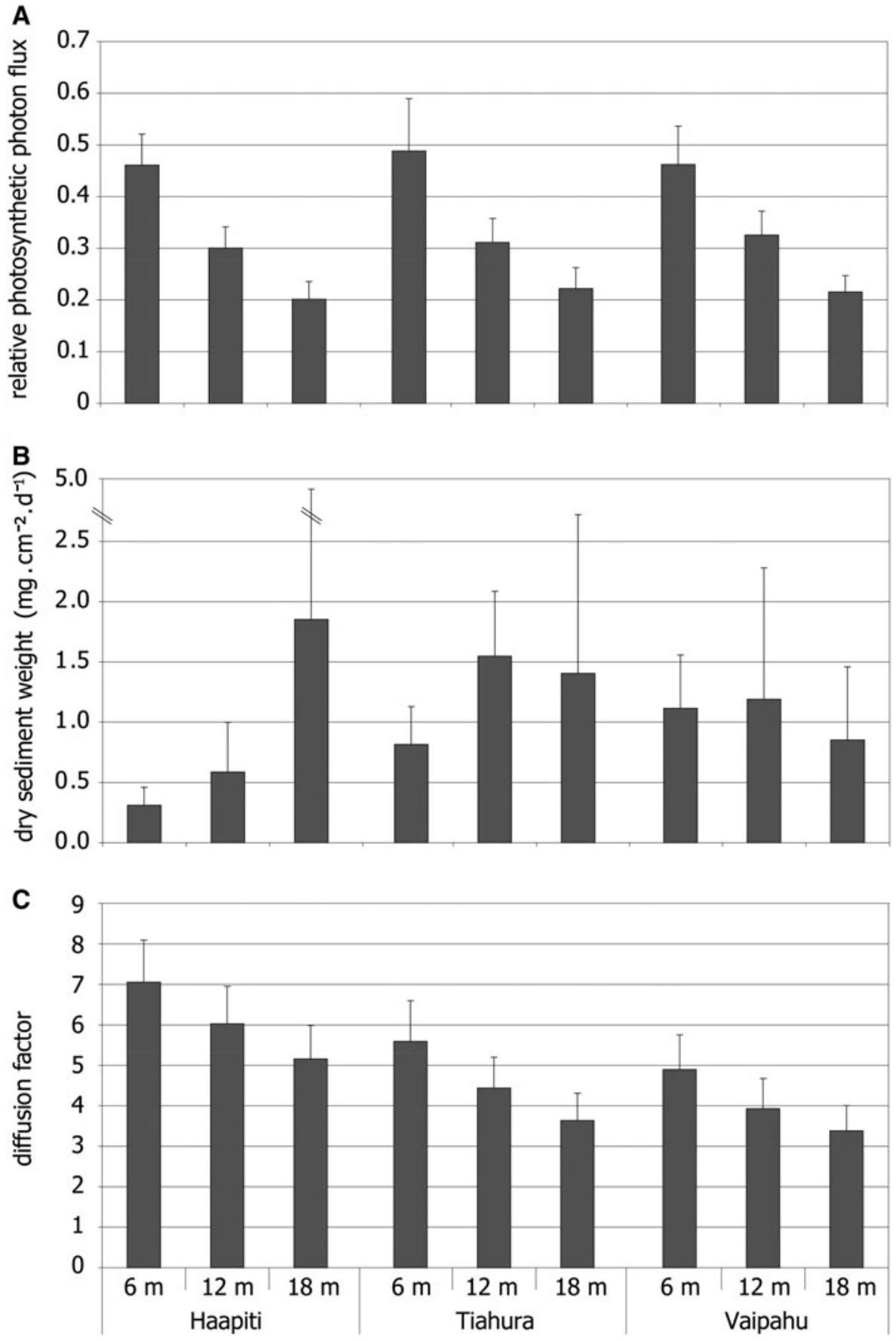

Fig. 4. Spatial variation of: (A) light intensity (relative photosynthetic photon flux $\mathrm{rPPF})$; (B) sedimentation (dry sediment weight, mg.cm ${ }^{-2}$.d ${ }^{-1}$ ); $(\mathrm{C})$ water motion (diffusion factor) over the nine stations. Error bars represent standard deviations.

depth, and significant differences were detected among locations, Haapiti presenting the highest values and Vaipahu the lowest (Figure 4; Table 2).

Spatial variability in Symbiodinium density was strongly and negatively correlated with light intensity, but not with sedimentation rates or water motion (Figure 5; Table 3).

\section{DISCUSSION}

Symbiodinium density observed in Acropora globiceps tissues around Moorea was of the same order of magnitude as values previously measured in A. palmata and A. cervicornis in the Caribbean (Fitt et al., 2000), in A. formosa in the Indian Ocean (Fagoonee et al., 1999), in different Acropora species in the South China Sea (Li et al., 2008), and also in A. millepora at the Palm Island Group, Great Barrier Reef, Australia (Moothien-Pillay et al., 2005). This suggests that the range of Symbiodinium density is relatively consistent within the Acropora genus, even for highly divergent host species and symbiont clades, and from different biogeographic regions or environmental conditions.

At the colony scale, results showed homogeneity of Symbiodinium densities between inner and outer branches 
Table 2. Kruskal-Wallis tests among stations $(N=9$ stations), among locations ( $N=3$ locations) and among depths $(N=3$ depths $)$ on light (photosynthetic photon flux), sedimentation (dry sediment weight), and water motion (diffusion factor). $\alpha_{1}$ (without Bonferroni correction) $=$ $0.0500 ; \alpha_{2}$ (with Bonferroni correction) $=0.0167$.

\begin{tabular}{|c|c|c|c|c|}
\hline Light & $\mathbf{H}$ & $P$ & sig. with $\alpha_{1}$ & sig. with $\alpha_{2}$ \\
\hline Station & 556.996 & $<0.0001$ & * & * \\
\hline Location & 2.540 & 0.2808 & NS & NS \\
\hline Depth & 552.520 & $<0.0001$ & $*$ & $*$ \\
\hline Sedimentation & $\mathbf{H}$ & $P$ & sig. with $\alpha_{1}$ & sig. with $\alpha_{2}$ \\
\hline Station & 42.670 & $<0.0001$ & $*$ & * \\
\hline Location & 18.662 & $<0.0001$ & * & $*$ \\
\hline Depth & 2.902 & 0.2343 & NS & NS \\
\hline Water motion & $\mathbf{H}$ & $P$ & sig. with $\alpha_{1}$ & sig. with $\alpha_{2}$ \\
\hline Station & 569.013 & $<0.0001$ & * & $*$ \\
\hline Location & 319.882 & $<0.0001$ & $*$ & $*$ \\
\hline Depth & 238.675 & $<0.0001$ & * & * \\
\hline
\end{tabular}

in A. globiceps at the Vaipahu site, regardless of the depth considered. This outcome seems in contradiction with results of previous surveys on other Acropora species (Oliver, 1984; Moothien-Pillay et al., 2005) and suggests that intra-colony variation in Symbiodinium density in reef-building corals could be species-specific. At Moorea, this absence of intracolony differences in Symbiodinium density could also be due to high light intensity $\left(>200 \mu \mathrm{mol} . \mathrm{m}^{-2} . \mathrm{s}^{-1}\right)$ and water motion $(>3.5$; Figure 4$)$ observed at all study sites and/or to the presence of only small differences in these parameters between internal and external branches, especially when considering the upper part of the branches, which usually contain less Symbiodinium (Allemand et al., 2011). These hypotheses could be addressed through intra-colony measurements of light intensity and water motion on different species of the Acropora genus.

At the station scale, no differences were observed among colonies in the density of Symbiodinium. This homogeneity within a particular habitat indicates the preponderance of extrinsic vs intrinsic factors, and suggests environmental factors are probably homogeneous enough at this scale not to induce significant variability in Symbiodinium density. At the location scale, a marked and consistent increase in Symbiodinium density with increasing depth was observed at all three locations. At the reef scale, significant differences in Symbiodinium density have been observed among the nine stations, but not among the three locations (Figure 3). This shows that variability in Symbiodinium density is mostly driven by depth and associated parameters such as light, rather than by location. This depth pattern is probably related to the strong negative correlation observed between light intensity and Symbiodinium density, and underlines the importance played by light in the coral-algal symbiosis (Falkowski et al., 1984). A similar depth/light pattern in Symbiodinium density was demonstrated in other cnidarians, such as other scleractinian corals (Drew, 1972; Dustan, 1979) or the sea anemone Aiptasia tagetes (Steele, 1976). Reduced light intensity is known to induce an increase of Symbiodinium density and photosynthetic pigments concentration under experimental conditions (Titlyanov et al., 2001) or in the field, in relation with depth (Li et al., 2008) or cloud cover (Titlyanov et al., 2001; Sunagawa et al., 2008). Titlyanov et al. (1980) have also established a relationship between the increase of Symbiodinium density and the decrease of light. These patterns are linked with acclimatization to low light, which involves maximization of the light harvesting capacity by increasing photosynthetic pigment concentration in Symbiodinium, and Symbiodinium population density in coral branches. Another mechanism for corals to acclimatize to low light may be to change their Symbiodinium clades (Rowan \& Knowlton, 1995; Toller et al., 2001; Bongaerts et al., 2010), in a similar way to that sometimes observed with acclimatization to high temperature (Stat et al., 2006). The different clades present variable volume and circumference (Wilkerson et al., 1988), and deeper corals generally harbour smaller Symbiodinium (Wilkerson et al., 1988). Moreover, there is a relation between the size and density of symbionts and the host tissue volume (space availability for symbionts; Jones \& Yellowlees, 1997). In the present study, we did not detect any visible difference in Symbiodinium size, and we can thus assume that variability in size of Symbiodinium, in order to counterbalance higher density, is probably limited. However, it would be of particular interest to examine this hypothesis in further studies aiming to precisely quantify and qualify the size and the clade of Symbiodinium extracted from Acropora globiceps sampled at different depth.

The observed higher Symbiodinium density at deep stations can also be one of the causes of spatial variability in corals response to high temperature observed during the

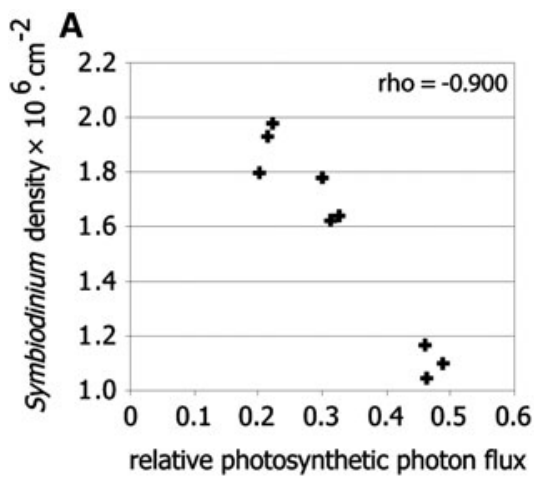

B

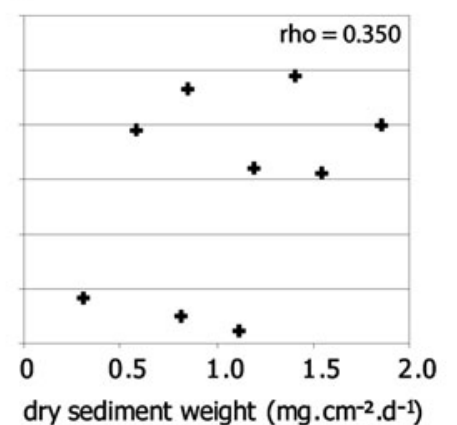

C

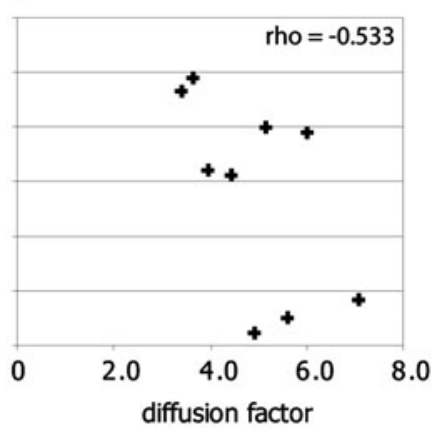

Fig. 5. Relationships between variation of Symbiodinium density (zoox.cm ${ }^{-2}$ ) and environmental factors among the nine stations: (A) light intensity (relative photosynthetic photon flux); (B) sedimentation (dry sediment weight, mg.cm ${ }^{-2} \cdot \mathrm{d}^{-1}$ ); (C) water motion (diffusion factor). rho is the Spearman's rank correlation coefficient. 
Table 3. Spearman non-parametric correlations between Symbiodinium density and environmental factors (light, sedimentation, and water motion). $\alpha_{1}$ (without Bonferroni correction) $=0.0500 ; \alpha_{2} \quad$ (with Bonferroni correction) $=0.0167$.

\begin{tabular}{lrlll}
\hline Factor & $\boldsymbol{\rho}$ & $\boldsymbol{P}$ & sig. with $\boldsymbol{\alpha}_{\mathbf{1}}$ & sig. with $\boldsymbol{\alpha}_{\mathbf{2}}$ \\
\hline Light & -0.900 & 0.0109 & $*$ & $*$ \\
Sedimentation & 0.350 & 0.3222 & NS & NS \\
Water motion & -0.533 & 0.1314 & NS & NS \\
\hline
\end{tabular}

bleaching event that occurred at Moorea a few weeks after this study. During this bleaching event, corals at deeper stations displayed a higher bleaching response than the shallower ones (Penin et al., 2013). Coral bleaching is clearly linked to photodamages faced by Symbiodinium under thermal stress (Venn et al., 2008). These damages cause overproduction of reactive oxygen species (ROS) leading to coral bleaching via a complex cellular cascade (Weis, 2008). As a consequence, corals from deeper stations, with high Symbiodinium density and high concentration of photosynthetic pigments might suffer from higher oxidative stress during temperature anomalies than corals at shallower stations, characterized by lower Symbiodinium and pigment densities (Stat et al., 2006).

Results of this study demonstrate that Symbiodinium density in Acropora globiceps is strongly influenced by light intensity, as it is the case for photophysiological and symbiotic mechanisms in reef-building coral species (Venn et al., 2008; Mass et al., 2010). Homogeneity in Symbiodinium density at the colony (i.e. between branches of the same colony) and station scales (i.e. between colonies of the same habitat) allows considering Symbiodinium density in A. globiceps as a potential biomarker of coral health in monitoring surveys, since Symbiodinium density seems typical of a particular habitat. In the present study, Symbiodinium density was measured in non-disturbed conditions (i.e. in the absence of major perturbations), just before the season when bleaching events generally occur (Penin et al., 2007, 2013), and at various depths and locations. Therefore, it provides a valuable baseline that could be used in the future as a reference, to be compared with measures realized in disturbed conditions, such as during a bleaching event. In this perspective, Symbiodinium density can represent an inexpensive and easy to implement biomarker of coral-Symbiodinium symbiosis health, and complement other tools used in studies investigating the effects of bleaching events on coral reef health.

\section{ACKNOWLEDGEMENTS}

We would like to thank CRIOBE staff for field logistics and support, and particularly Yannick Chancerelle, Pascal Ung, Pauline Bosserelle, and volunteers of Planète Urgence for logistical help in data collection.

\section{FINANCIAL SUPPDRT}

We would like to acknowledge the following financial support: FNRS (Fonds National de la Recherche Scientifique, Belgium) O.L. and S.R.; European Marie Curie Outgoing Fellowship (PIOF-GA-2008-220798)-L.P.; La Polynésienne des Eaux (French Polynesia) and Planète Urgence, Franceo - M.K.

\section{REFERENCES}

Adjeroud M. (1997) Factors influencing spatial patterns on coral reefs around Moorea, French Polynesia. Marine Ecology Progress Series 159, $105-119$.

Adjeroud M., Chancerelle Y., Schrimm M., Perez T., Lecchini D., Galzin R. and Salvat B. (2005) Detecting the effects of natural disturbances on coral assemblages in French Polynesia: a decade survey at multiple scales. Aquatic Living Resources 18, 111-123.

Adjeroud M., Michonneau F., Edmunds P.J., Chancerelle Y., Lison de Loma T., Penin L., Thibaut L., Vidal-Dupiol J., Salvat B. and Galzin R. (2009) Recurrent disturbances, recovery trajectories, and resilience of coral assemblages on a South Central Pacific reef. Coral Reefs 28, 775-780.

Allemand D., Tambutté E., Zoccola D. and Tambutté S. (2011) Coral calcification, cells to reef. In Dubinsky Z. and Stambler N. (eds) Coral reef: an ecosystem in transition. Amsterdam: Springer, pp. $119-150$.

Baker A.C., Glynn P.W. and Riegl B. (2008) Climate change and coral reef bleaching: an ecological assessment of long-term impacts, recovery trends and future outlook. Estuarine, Coastal and Shelf Science $80,435-471$.

Bhagooli R. and Yakovleva I. (2004) Differential bleaching susceptibility and mortality patterns among four corals in response to thermal stress. Symbiosis $37,121-136$.

Bongaerts P., Riginos C., Ridgway T., Sampayo E.M., van Oppen M.J.H., Englebert N., Vermeulen F. and Hoegh-Guldberg O. (2010) Genetic divergence across habitats in the widespread coral Seriatopora hystrix and its associated Symbiodinium. PLOS ONE 5(5), e10871.

Brodie J., De'ath G., Devlin M., Furnas M. and Wright M. (2007) Spatial and temporal patterns of near-surface chlorophyll- $a$ in the Great Barrier Reef lagoon. Marine and Freshwater Research 58, 342-353.

Cabin R.J. and Mitchell R.J. (2000) To Bonferroni or not to Bonferroni: when and how are the questions. Bulletin of the Ecological Society of America 81, 246-248.

Chancerelle Y. (2000) Méthodes d'estimation des surfaces développées de coraux scléractiniaires à l'échelle d'une colonie ou d'un peuplement. Oceanologica Acta 23, 211-219.

D’Croz L., Maté J.L. and Oke J.E. (2001) Responses to elevated sea water temperature and UV radiation in the coral Porites lobata from upwelling and non-upwelling environments on the Pacific coast of Panama. Bulletin of Marine Science 69, 203-214.

Douglas A.E. (2003) Coral bleaching-how and why? Marine Pollution Bulletin 46, 385-392.

Drew E.A. (1972) The biology and physiology of alga-invertebrates symbioses. II. The density of symbiotic algal cells in a number of hermatypic hard corals and alcyonarians from various depths. Journal of Experimental Marine Biology and Ecology 9, 71-75.

Dustan P. (1979) Distribution of zooxanthellae and photosynthetic chloroplast pigments of the reef-building coral Montastrea annularis (Ellis and Solander) in relation to depth on a West Indian coral reef. Bulletin of Marine Science 29, 79-95.

Fagoonee I., Wilson H.B., Hassell M.P. and Turner J.R. (1999) The dynamics of zooxanthellae populations: a long-term study in the field. Science 283(5403), 843-845.

Falkowski P.G., Dubinsky Z., Muscatine L. and Porter J.W. (1984) Light and the bioenergetics of a symbiotic coral. Bioscience 34, 705-709.

Finelli C., Helmuth B., Pentcheff N. and Wethey D. (2006) Water flow influences oxygen transport and photosynthetic efficiency in corals. Coral Reefs 25, 47-57. 
Fitt W., Brown B., Warner M. and Dunne R. (2001) Coral bleaching interpretation of thermal tolerance limits and thermal thresholds in tropical corals. Coral Reefs 20, 51-65.

Fitt W.K., McFarland F.K., Warner M.E. and Chilcoat G.C. (2000) Seasonal patterns of tissue biomass and densities of symbiotic dinoflagellates in reef corals and relation to coral bleaching. Limnology and Oceanography 45, 677-685.

Frade P.R., De Jongh F., Vermeulen F., Van Bleijswijk J. and Bak R.P.M. (2008a) Variation in symbiont distribution between closely related coral species over large depth ranges. Molecular Ecology 17 $691-703$.

Frade P.R., Englebert N., Faria J., Visser P.M. and Bak R.P.M. (2008b) Distribution and photobiology of Symbiodinium types in different light environments for three colour morphs of the coral Madracis pharensis: is there more to it than total irradiance? Coral Reefs 27 , 913-925.

Goreau T. and Hayes R. (1994) Coral bleaching and ocean 'Hot spots'. Ambio 23, 176-180.

Hallock P. (2001) Coral reefs, carbonate sedimentation, nutrients, and global change. In Stanley G. (eds) The history and sedimentology of ancient reef ecosystems. New York: Kluwer Academic/Plenum Publishers, pp. 387-427.

Hoegh-Guldberg O. and Smith G.J. (1989) The effect of sudden changes in temperature, light and salinity on the population density and export of zooxanthellae from the reef corals Stylophora pistillata Esper and Seriatopora hystrix Dana. Journal of Experimental Marine Biology and Ecology 129, 279-303.

Jones R.J. and Yellowlees D. (1997) Regulation and control of intracellular algae (= zooxanthellae) in hard corals. Philosophical Transactions of the Royal Society of London Series B-Biological Sciences 352, 457-468.

Kayal M., Lenihan H., Pau C., Penin L. and Adjeroud M. (2011) Associational refuges among corals mediate impacts of a crown-of-thorns starfish Acanthaster planci outbreak. Coral Reefs 30, $827-837$.

Lasker H.R. (2003) Zooxanthella densities within a Caribbean octocoral during bleaching and non-bleaching years. Coral Reefs 22, 23-26.

Leal M.C., Nunes C., Alexandre D., Silva T.L.d., Reis A., Dinis M.T. and Calado R. (2012) Parental diets determine the embryonic fatty acid profile of the tropical nudibranch Aeolidiella stephanieae: the effect of eating bleached anemones. Marine Biology 159, 1745-1751.

Lesser M., Stochaj W., Tapley D. and Shick J. (1990) Bleaching in coral reef anthozoans: effects of irradiance, ultraviolet radiation, and temperature on the activities of protective enzymes against active oxygen. Coral Reefs 8, 225-232.

Li S., Yu K.F., Shi Q., Chen T.R., Zhao M.X. and Zhao J.X. (2008) Interspecies and spatial diversity in the symbiotic zooxanthellae density in corals from northern South China Sea and its relationship to coral reef bleaching. Chinese Science Bulletin 53, 295-303.

Marshall P.A. and Baird A.H. (2000) Bleaching of corals on the Great Barrier Reef: differential susceptibilities among taxa. Coral Reefs 19, $155-163$.

Mass T., Kline D.I., Roopin M., Veal C.J., Cohen S., Iluz D. and Levy O. (2010) The spectral quality of light is a key driver of photosynthesis and photoadaptation in Stylophora pistillata colonies from different depths in the Red Sea. Journal of Experimental Biology 213, 40844091.

McClanahan T.R., Weil E., Cortés J., Baird A.H. and Ateweberhan M. (2009) Consequences of coral bleaching for sessile reef organisms. In van Oppen M.J.H. and Lough J.M. (eds) Coral bleaching. Berlin: Springer, pp. $121-138$.
Moothien-Pillay R.M., Willis B. and Terashima H. (2005) Trends in the density of zooxanthellae in Acropora millepora (Ehrenberg, 1834) at the Palm Island Group, Great Barrier Reef, Australia. Symbiosis 38, 209-226.

Moran M.D. (2003) Arguments for rejecting the sequential Bonferroni in ecological studies. Oikos 100, 403-405.

Muscatine L. and Porter J.W. (1977) Reef corals-mutualistic symbioses adapted to nutrient-poor environments. Bioscience 27, 454-460.

Oliver J.K. (1984) Intra-colony variation in the growth of Acropora formosa: extension rates and skeletal structure of white (zooxanthellaefree) and brown-tipped branches. Coral Reefs 3, 139-147.

Penin L., Adjeroud M., Schrimm M. and Lenihan H. (2007) High spatial variability in coral bleaching around Moorea (French Polynesia): patterns across locations and water depths. Comptes Rendus Biologies 330, $171-181$.

Penin L., Vidal-Dupiol J. and Adjeroud M. (2013) Response of coral assemblages to thermal stress: are bleaching intensity and spatial patterns consistent between events? Environmental Monitoring and Assesment 185, 5031-5042.

Rowan R. and Knowlton N. (1995) Intraspecific diversity and ecological zonation in coral-algal symbiosis. Proceedings of the National Academy of Sciences of the United States of America 92, $2850-2853$.

Salvat B. The 1991 bleaching event in the Society Islands, French Polynesia. In Proceedings of the Proceedings of the 7 th International Coral Reef Symposium, Guam, 22-27 June 1992. Guam: University of Gaum Press, p. 73.

Sawall Y., Teichberg M., Seemann J., Litaay M., Jompa J. and Richter C. (2011) Nutritional status and metabolism of the coral Stylophora subseriata along a eutrophication gradient in Spermonde Archipelago (Indonesia). Coral Reefs 30, 841-853.

Shenkar N., Fine M., Kramarsky-Winter E. and Loya Y. (2006) Population dynamics of zooxanthellae during a bacterial bleaching event. Coral Reefs 25, 223-227.

Stat M., Carter D. and Hoegh-Guldberg O. (2006) The evolutionary history of Symbiodinium and scleractinian hosts-Symbiosis, diversity, and the effect of climate change. Perspectives in Plant Ecology, Evolution and Systematics 8, 23-43.

Steele R.D. (1976) Light intensity as a factor in the regulation of the density of symbiotic zooxanthellae in Aiptasia tagetes (Coelenterata, Anthozoa). Journal of Zoology 179, 387-405.

Steen R.G. and Muscatine L. (1987) Low temperature evokes rapid exocytosis of symbiotic algae by a sea anemone. Biological Bulletin. Marine Biological and Laboratory, Woods Hole 172, 246-263.

Stewart G.J., Caldwell J.M., Cloutier A.R. and Flight L.E. (2006) Water Resources Data-Maine Water Year 2005. Augusta, ME: Maine Water Science Center.

Stimson J., Sakai K. and Sembali H. (2002) Interspecific comparison of the symbiotic relationship in corals with high and low rates of bleaching-induced mortality. Coral Reefs 21, 409-421.

Sunagawa S., Cortes J., Jimenez C. and Lara R. (2008) Variation in cell densities and pigment concentrations of symbiotic dinoflagellates in the coral Pavona clavus in the eastern Pacific (Costa Rica). Ciencias Marinas 34, 113-123.

Thompson T.L. and Glenn E.P. (1994) Plaster standards to measure water motion. Limnology and Oceanography 39, 1768-1779.

Titlyanov E.A., Shaposhnikova M.G. and Zvalinskii V.I. (1980) Photosynthesis and adaptation of corals to irradiance. 1. Contents and native-state of photosynthetic pigments in symbiotic microalga. Photosynthetica 14, 413-421. 
Titlyanov E.A., Titlyanova T.V., Yamazato K. and van Woesik R. (2001) Photo-acclimation dynamics of the coral Stylophora pistillata to low and extremely low light. Journal of Experimental Marine Biology and Ecology 263, 211-225.

Toller W.W., Rowan R. and Knowlton N. (2001) Zooxanthellae of the Montastraea annularis species complex: patterns of distribution of four taxa of Symbiodinium on different reefs and across depths. Biological Bulletin. Marine Biological and Laboratory, Woods Hole 201, 348-359.

Venn A.A., Loram J.E. and Douglas A.E. (2008) Photosynthetic symbioses in animals. Journal of Experimental Botany 59, 1069-1080.

Wallace C. (1999) Staghorn corals of the world: a revision of the genus Acropora. Collingwood, Victoria: CSIRO Publishing.

Weis V.M. (2008) Cellular mechanisms of cnidarian bleaching: stress causes the collapse of symbiosis. Journal of Experimental Biology $211,3059-3066$. and

Wilkerson F.P., Kobayashi D. and Muscatine L. (1988) Mitotic index and size of symbiotic algae in Caribbean reef corals. Coral Reefs 7 , $29-36$.

\section{Correspondence should be addressed to:}

L. Penin

Laboratoire d'Écologie Marine, FRE CNRS UR 3560 ECOMAR and Laboratoire d'Excellence

'CORAIL', Université de La Réunion, BP 7151, 97715 Saint-Denis Cedex 09, Réunion Island,

France

email: lucie.penin@univ-reunion.fr 